\title{
Mirabegron Role in Urolithiasis Management: What you should Know
}

\section{Rol del mirabegrón en el manejo de la urolitiasis: Lo que usted debe saber}

\author{
Eduar S. Rodríguez ${ }^{1(i)}$ David Naranjo ${ }^{1(0)}$ \\ ${ }^{1}$ Department of Urology, Universidad El Bosque, Bogotá, Colombia \\ Address for correspondence Eduar S. Rodríguez, MD, Department of \\ Urol Colomb 2021;30:74-76. \\ Urology, Universidad El Bosque, Carrera 15 № 135-81, Bogotá, \\ Colombia (e-mail: shellender@hotmail.com).
}

\begin{abstract}
Keywords

- mirabegron

- medical expulsive therapy

- urolithiasis

- ureteroscopy

- ureteral catheter

- double-J catheter

\section{Resumen}

Palabras clave

- mirabegrón

- terapia médica expulsiva

- urolitiasis

- ureteroscopia

- catéter ureteral

- catéter doble J
\end{abstract}

The purpose of the present study was to develop a narrative review of the available evidence of mirabegron efficacy in three scenarios: as a medical expulsive therapy; as a medical treatment to increase a successful access to stones before ureteroscopy, and management of double-J stent-related symptoms. Only two original studies have evaluated its use as a medical expulsive therapy, with contradictory results in terms of stone expulsion rate; however, both demonstrated a better pain control in the mirabegron group. One randomized controlled trial (RCT) found a higher successful access to ureteral stones when mirabegron was administered 1 week before the ureteroscopy. And two RCTs demonstrated its efficacy in diminishing discomfort related with double-J stent. There is a promising role for the use of mirabegron in the arsenal of urolithiasis treatment, even as a medical expulsive therapy, before ureteroscopy surgery, to increase the successful access to the stones and after the placement of ureteral catheter to reduce the related symptoms. However, larger-scaled prospective double-blinded RCTs are needed before it can be used with these purposes in the clinical scenario.

El propósito de este trabajo fue desarrollar una revisión narrativa de la literatura describiendo la evidencia disponible sobre la eficacia del mirabegrón en tres escenarios: como terapia médica expulsiva, como tratamiento médico antes de la ureteroscopia para incrementar el acceso exitoso al cálculo, y en el manejo de los síntomas asociados con el uso de catéter doble J. Solo dos estudios originales han evaluado su uso como terapia médica expulsiva, con resultados contradictorios en términos de tasa de expulsión del cálculo; sin embargo, ambos demostraron mejor control del dolor en el grupo de mirabegrón. Un estudio aleatorizado multicéntrico encontró un aumento en el acceso exitoso al cálculo durante la ureteroscopia cuando el mirabegrón era administrado una semana antes del procedimiento. Adicionalmente, dos estudios aleatorizados controlados demostraron eficacia del medicamento para disminuir los received

January 27, 2020

accepted

June 17,2020

published online

August 14, 2020
DOI https://doi.org/

10.1055/s-0040-1714727.

ISSN 0120-789X.

e ISSN 2027-0119. (c) 2020. Sociedad Colombiana de Urología. All rights reserved. This is an open access article published by Thieme under the terms of the Creative Commons Attribution-NonDerivative-NonCommercial-License, permitting copying and reproduction so long as the original work is given appropriate credit. Contents may not be used for commercial purposes, or adapted, remixed, transformed or built upon. (https://creativecommons.org/ licenses/by-nc-nd/4.0/)

Thieme Revinter Publicações Ltda., Rua do Matoso 170, Rio de Janeiro, RJ, CEP 20270-135, Brazil 
síntomas relacionados con el catéter doble J. El uso del mirabegrón como parte del arsenal del tratamiento para urolitiasis tiene un rol prometedor, tanto en la terapia médica expulsiva como antes de la ureteroscopia, para aumentar la posibilidad de acceder exitosamente al cálculo, y en pacientes con catéter doble J, para disminuir los síntomas asociados. Sin embargo, se requiere estudios más grandes, prospectivos, doble ciegos y aleatorizados antes de que podamos utilizarlo con estos fines en un escenario clínico.

\section{Introduction}

Medical expulsive therapy involves the administration of drugs to obtain higher stone expulsion rates. Tamsulosin is the most used medication with this purpose. ${ }^{1}$ Some metaanalyses and randomized controlled trials (RCTs) have confirmed its efficacy. ${ }^{2,3}$ However, others have found contradictory results and the controversy still exists. ${ }^{4}$ Consequently, there remains an interest to study other drugs which can achieve the goal. $\beta 3$-Adrenergic receptor ( $\beta 3-A R)$ agonists used for overactive bladder (OAB) like mirabegron have enough evidence. ${ }^{5}$ As it promotes relaxation of the smooth muscle of the bladder, it was supposed to have the same effect on the ureter. The purpose of the present article was to describe the available evidence of mirabegron efficacy in three scenarios: as a medical expulsive therapy; as a medical treatment to increase a successful access to stones before ureteroscopy; and management of double-J stent-related symptoms.

\section{Methods}

A search was made in the PubMed, ClinicalKey and ScienceDirect databases, using the following keywords: mirabegron, $\beta$-adrenergic receptor, $\beta 3$ agonist, medical expulsive therapy, urolithiasis, ureteroscopy, ureteral catheter and double-J catheter. All of the original studies published in English were used. Using the recompiled data, a narrative review of the literature was performed.

\section{Results}

\section{Expression of $\boldsymbol{\beta}$-adrenergic Receptors in the Ureter}

Wanajo et al studied the presence of $\beta$-adrenoreceptors in the ureter of porcine segments, proving the existence of $\beta 2$ and $B 3-A R$ in the ureteric smooth muscle, in the urothelium and in the interstitial cells. ${ }^{6}$ In 2013, Matsumoto et al confirmed the expression of $\beta 1, \beta 2$ and $\beta 3-A R$ in the smooth muscle and in the urothelium of the human ureter, including proximal, middle and distal segments. They also demonstrated that its stimulation by $\beta 3$-agonists decreased ureter muscle contractions in a concentration-dependent manner. ${ }^{7}$

Shen et al compared the expression of $\beta$-AR subtypes in human normal and dilated ureters. Their results showed that $\beta 3$-AR expression were decreased by $53.62 \%(p<0.01)$ in the muscular layer of the lower segment of the dilated ureter, suggesting a possible physiological compensatory mechanism which results in an increased contraction of the ureter to propel urine through the obstructed lumen. ${ }^{8}$ Hence, the potential role for mirabegron as a medical expulsive therapy arised. ${ }^{9}$

\section{Efficacy of Mirabegron in Medical Expulsive Therapy}

A retrospective study conducted in Turkey included 80 patients with distal ureteral stones and distributed them into 2 groups: $1(n=40)$ received mirabegron $50 \mathrm{mg} /$ day plus diclofenac $100 \mathrm{mg} /$ day, while the second group $(n=40)$ was treated with diclofenac $100 \mathrm{mg} /$ day alone. The results revealed a higher stone expulsion rate in group 1 ( 73.52 versus $47.05 \%$ in group 2 , $p=0.026)$, especially when the stone size was $\leq 6 \mathrm{~mm}(87.5$ versus $52.49 \%, p=0.031$ ). They also showed less pain episodes $(1.02 \pm 0.52$ versus $1.29 \pm 0.57, p=0.049){ }^{10}$

In contrast, Bayar et al recently published a prospective multicentric study with 169 patients included, all with ureter stones sized between 4 and $10 \mathrm{~mm}$ located proximally, medially or distally. They were divided into 3 groups by randomization: group 1 was the control group; group 2 took silodosin $8 \mathrm{mg} /$ day, and group 3 took mirabegron $50 \mathrm{mg}$ once daily. They found no relevant effect on stone expulsion intervals with the use of mirabegron $(9.8 \pm 4.7)$ compared with the control group $(12.3 \pm 4.3)(p=0.003)$. However, in patients with distal stones, the need for an analgesic was reduced in the mirabegron group $(1.8 \pm 1.9)$, compared with the control group $(3.6 \pm 2.3)$, respectively $(p=0.004) .^{11}$

\section{Mirabegron Use before Semi-rigid Ureterolithotripsy}

Bayar et al also documented mirabegron use before ureteroscopy. The idea was based in the relaxing effect provided by stimulating $\beta 3$-AR, that could provide easier access to ureteral stones. They developed a prospective, single blind, multicentric study using tamsulosin and mirabegron, associated with analgesics previous to ureteral stone intervention. The study design divided patients into three groups: the control group only used diclofenac $50 \mathrm{mg}$ (63 patients); the second group received tamsulosin $0.4 \mathrm{mg}$ with diclofenac $50 \mathrm{mg}$ (61 patients); and the third group used mirabegron $50 \mathrm{mg}$ with diclofenac (62 patients). The successful access to stones was statistically higher in the tamsulosin and mirabegron group (96.7\% and $95.2 \%$, respectively [ $p=0.003])$. They concluded that tamsulosin or mirabegron increases the successful access to ureteral stones using the medication 1 week before the ureteroscopy. ${ }^{12}$ 


\section{Management of Double-J Stent Related Symptoms}

Research on mirabegron has also been focused in reducing discomfort related with the ureteral stent placed after ureteroscopic surgeries. In a prospective multicentric study, 100 patients with double-J stent following endoscopic uretero or nephrolithotomy were included. Subjects were randomized (1:1) into 2 groups: one received mirabegron $50 \mathrm{mg}$ once daily until the removal of the stent, and the second group was the control group. Both of them also took standard analgesic medication during the stenting period. Authors found that the pain score (visual analogue scale [VAS]) was lower in the mirabegron group than in the control group (5.58 versus 2.83, $p=0.002$ ). Interestingly, they also noted that the change of the international prostate symptom score (IPSS) storage symptom score was lower in the mirabegron group $(3.58 \pm 3.58$ versus $1.83 \pm 4.39, p=0.035) .{ }^{13}$

Other authors have also studied mirabegron effects in symptoms related to double-J stent. Sahin et al conducted a trial comparing mirabegron versus tamsulosin/solifenacin combination in 120 patients using double-J stent. They randomly divided their patients in three groups: the control group only received oral hydration for 6 weeks; the second group took tamsulosin $0.4 \mathrm{mg}$ plus solifenacin $10 \mathrm{mg}$; and the third group took mirabegron $50 \mathrm{mg} /$ day. Mirabegron demonstrated a decrease in low urinary tract symptoms (LUTS), quantified by the IPSS value $(13.65 \pm 4.97$ versus $15.6 \pm 4.37$ versus $21.78 \pm$ 2.54 , compared with the tamsulosin/solifenacin combination and the hydration groups, respectively [ $p=0.001]$ ), especially those related with OAB. There was no significant difference in the pain score (VAS) between the groups.

\section{Conclusions}

$\beta 3$-adrenergic receptors are present in the urothelium and smooth muscle of human ureters. Their stimulation by $\beta 3-$ agonists like mirabegron results in a relaxation effect. The actual available evidence of its efficacy as a medical expulsive therapy is limited but promising. Other possible scenarios in which it could be used include the management of double-J stent-related symptoms and before ureteroscopy to increase the successful access to stones. However, larger-scaled prospective double-blinded RCTs are needed before it can be used in a real-life scenario.

\section{References}

1 Türk C, Knoll T, Seitz C, Skolarikos A, Chapple C, McClinton S; European Association of Urology. Medical Expulsive Therapy for
Ureterolithiasis: The EAU Recommendations in 2016. Eur Urol 2017;71(04):504-507. Doi: 10.1016/j.eururo.2016.07.024

2 Hollingsworth JM, Canales BK, Rogers MAM, et al. Alpha blockers for treatment of ureteric stones: systematic review and metaanalysis. BMJ 2016;355:i6112. Doi: 10.1136/bmj.i6112

3 Ye Z, Zeng G, Yang H, et al. Efficacy and Safety of Tamsulosin in Medical Expulsive Therapy for Distal Ureteral Stones with Renal Colic: A Multicenter, Randomized, Double-blind, Placebo-controlled Trial. Eur Urol 2018;73(03):385-391. Doi: 10.1016/j. eururo.2017.10.033

4 De Coninck V, Antonelli J, Chew B, Patterson JM, Skolarikos A, Bultitude M. Medical Expulsive Therapy for Urinary Stones: Future Trends and Knowledge Gaps. Eur Urol 2019;76(05): 658-666. Doi: 10.1016/j.eururo.2019.07.053

5 Chapple CR, Cruz F, Cardozo L, et al. Safety and Efficacy of Mirabegron: Analysis of a Large Integrated Clinical Trial Database of Patients with Overactive Bladder Receiving Mirabegron, Antimuscarinics, or Placebo. Eur Urol 2019;•••;. Doi: 10.1016/j.eururo.2019.09.024

6 Wanajo I, Tomiyama Y, Yamazaki Y, Kojima M, Shibata N. Pharmacological characterization of $\beta$-adrenoceptor subtypes mediating relaxation in porcine isolated ureteral smooth muscle. J Urol 2004;172(03):1155-1159. Doi: 10.1097/01.ju.0000133557.3951 $5 . \mathrm{b} 6$

7 Matsumoto R, Otsuka A, Suzuki T, et al. Expression and functional role of $\beta 3$-adrenoceptors in the human ureter. Int J Urol 2013;20 (10):1007-1014. Doi: 10.1111/iju.12093

8 Shen $\mathrm{H}$, Chen $\mathrm{Z}$, Mokhtar AD, et al. Expression of $\beta$-adrenergic receptor subtypes in human normal and dilated ureter. Int Urol Nephrol 2017;49(10):1771-1778. Doi: 10.1007/s11255-017-1667-y

9 Urkmez A, Tokuc E, Topaktas R, Sahin A, Yuksel OH. Mirabegron: A novel and promising medical expulsive treatment for ureteral stones? J Coll Physicians Surg Pak 2019;29(01):73-74. Doi: 10.29271/jcpsp.2019.01.73

10 Solakhan M, Bayrak O, Bulut E. Efficacy of mirabegron in medical expulsive therapy. Urolithiasis 2019;47(03):303-307. Doi: 10.1007/s00240-018-1075-5

11 Bayar G, Yavuz A, Cakmak S, et al. Efficacy of silodosin or mirabegron in medical expulsive therapy for ureteral stones: a prospective, randomized-controlled study. Int Urol Nephrol 2019;•..;. Doi: 10.1007/s11255-019-02368-y

12 Bayar G, Kilinc MF, Yavuz A, Aydın M. Adjunction of tamsulosin or mirabegron before semi-rigid ureterolithotripsy improves outcomes: prospective, randomized single-blind study. Int Urol Nephrol 2019;51(06):931-936. Doi: 10.1007/s11255-01902142-0

13 Tae BS, Cho S, Jeon BJ, et al. Does mirabegron relieve ureteric stent-related discomfort? A prospective, randomized, multicentre study. BJU Int 2018;122(05):866-872. Doi: 10.1111/ bju. 14416

14 Sahin A, Yildirim C, Yuksel OH, Urkmez A. Treatment of ureteral catheter related symptoms; mirabegron versus tamsulosin/solifenacin combination: A randomized controlled trial. Arch Esp Urol 2020;73(01):54-59http://www.ncbi.nlm.nih.gov/pubmed/ 31950924 